\title{
Doktor Tabloid
}

\author{
Når helseministeren ringer for sent til en intervjuavtale, må han pent vente \\ til Charlotte Lunde får puttet rosinboller i barna.
}

- Altså; vi hadde egentlig avtalt at han skulle ringe en time tidligere. Jeg skulle intervjue ham om samhandlingsreformen for Journalen, medlemsblad for Oslo legeforening, sier Charlotte Lunde. Det var Bjarne Håkon Hanssen som måtte vente. Han tok det greit.

\section{Kjøkkenveien}

- Jeg kom kjøkkenveien inn i journalistikken, forteller Charlotte. Mens hun studerte litteraturvitenskap, jobbet hun i Radio Nova, studentradioen i Oslo. Dette er absolutt ikke et dumt sted å begynne for folk med ambisjoner innen mediene. Kanalen har nærmest fungert som utklekkingsanstalt for NRK, og kjente navn som Anders Heger, Anne Lindmo og Harald Eia har jobbet her. Charlotte startet karrieren som musikkjournalist i Radio Nova, og fortsatte på samme vis i musikkmagasinet Beat og gratisavisen Natt\&Dag. Hun er den eneste norske journalisten som har intervjuet grungebandet Nirvana. De opplevde en enorm popularitet tidlig i 1990-årene.

Journalistikken var lenge, eller kanskje alltid, noe hun bare holdt på med ved siden av studiene.

- Det høres nesten ut som om jobbene i dagspressen kom «rekende på ei fjøl»?

- Dette var ikke noen bevisst karrierevei for meg, nei. Jeg tok noen fag på Blindern og jobbet som journalist og hadde vel ikke noe bestemt mål før jeg begynte på medisin, forteller Charlotte. Hun pleier å si at hun hadde noen «protestår i journalistikken». - Mulig at det er kokettering, men jeg er arvelig belastet med medisin. I likhet med jus er medisin et av de mest arvelige fagene som finnes. Jeg er tredje generasjon lege. Farfar var barnelege i Arendal, så nå er kanskje ringen sluttet, filosoferer hun, men legger til: - Journalistikken kommer nok til å følge meg videre på en eller annen måte.

\section{Vendepunkt}

- Hvorfor forlot du en lovende karriere innen mediebransjen for å begynne på medisin?

- Jeg tenkte virkelig aldri at jeg skulle bli lege da jeg var yngre. Jeg likte ikke naturfag, spesielt ikke matte, sier hun. Interessen for disse fagene ble vakt da hun en sommer jobbet i NRK med en miljøvernserie for barn. - Samtidig begynte jeg å kjenne på en økende frustrasjon i journalistikken, forteller Charlotte. - Jeg holdt på med musikk- og kulturjournalistikk den gangen. Fordi mediene er underlagt kommersielle krav, ble de mer og mer kjendisfokusert. Min idé med skrivingen, folkeopplysningstanken, forsvant liksom. Parallelt skulle jeg begynne på hovedfag i litteraturvitenskap der tema var de første urbanister i norsk litteratur. Men jeg orket ikke tanken på å skrive noe som bare jeg og veilederen min skulle lese. Jeg måtte ut og virke i verden, gjøre noe konkret! Dermed ble det medisin.

- Valgte du også et «tryggere» liv?

- Neeei..., hun trekker på det. - Det hadde vært tryggere å bli der jeg var. Selvfølgelig måtte jeg spørre meg selv: Blir du fornøyd nå da? Jeg var vant til å få jobbtilbud. Nå må jeg ut og søke på halvårsvikariater. Men medisin er en god og grundig utdanning og en faglig plattform med fantastiske muligheter.

Charlotte tenker seg litt om. - Jeg håper at jeg kan finne en nisje der jeg også kan bruke formidlingsbakgrunnen min. Hun trekker frem at det både er et krav til og en økende interesse hos forskere om å nå ut til vanlige folk. Selv har hun undervist medisinske doktorgradsstipendiater i mediehåndtering.

\section{Dannelse}

- Jeg hadde en romantisk forestilling om hvor musikalske og sosialt engasjerte medisinstudentene var. Jeg så på medisinstudiet som et dannelsesfag. Om jeg ble skuffet? Nei, nei, det må du ikke skrive i Tidsskriftet. Det finnes så mange flotte og allsidige medisinstudenter og leger, men de dyrker som oftest sin allsidighet andre steder enn i faget. Det er litt trist.

Hun forteller om sin første histologitime: - Det var så vakkert! Ovariet til en katt, kunne det virkelig se så fint ut liksom? Det finnes professorer med mye glede og humor i faget også, men verden ble veldig fort veldig flat.

\section{Handler om menneskemøter}

- Hva sier dagens journalister? spurte alltid professor i nevrologi Helge Nordal dem som hadde tatt opp journal av klinikkpasienten. Hvilke likheter og forskjeller ser du mellom de to yrkene?

- Begge har nysgjerrighet som drivkraft.
Som leger skal vi bruke den informasjonen vi får til å hjelpe pasienten, og taushetsplikten er en helt annen kontrakt enn den journalister opererer under. Journalisten forholder seg ikke på samme måte overfor sitt intervjuobjekt, innimellom tvert om. Begge yrkene handler om menneskemøter og om å skape den tilliten det kreves for å spørre folk om personlige og ofte problematiske ting, mener Charlotte. Hun påpeker at begge spør seg frem til en problemstilling, at begge må bruke både erfaring, kunnskap og intuisjon og ofte sile ut unyttig informasjon. - Journalistikken gjorde det nok lettere for meg med anamneseopptak og har lært meg å skrive konsise journaler. Journalen er jo også en sjanger.

\section{Hierarki}

Charlotte medgir at det ikke bare har vært lett å komme inn i et system som helsevesenet. Særlig ikke med bakgrunn i journalistikken, der man fritt oppsøker alle kilder uavhengig av status.

Det å kontakte spesialistene innen et felt har jeg med meg inn i medisinen. Om jeg lurer på noen angående vanskelige pasienter, hender det at jeg ringer professorer jeg kjenner til.

- Du er ikke redd for å virke dum?

- I løpet av studiet var jeg redd for det. Da skal vi alle liksom være så flinke. Men ikke nå lenger, heldigvis. Det er bedre å være i jobb.

- Og ingen har reagert negativt?

- Nei, jeg har bare fått hyggelige reaksjoner til nå. Dersom en «overhofflege» synes det er irriterende at en nyutdannet vil diskutere et faglig spørsmål i arbeidstiden, er det litt rart, mener jeg.

Hun har også sterke meninger om hvordan vi forholder oss til hverandre på jobb. - Kommunikasjonsformene både innad i kollegiene og mellom de ulike faggruppene er noen steder preget av inngrodd hierarki. Jeg mener det er rester av en gammel tid og at det verken kommer oss eller pasientene til gode. I psykiatrien har de en mer flat struktur der flere faggrupper har en like verdifull stemme. Kanskje det er en bedre måte å samarbeide på?

Hun syns det er flott at det undervises i kommunikasjon på studiet, men at denne kunnskapen ikke ennå preger den kliniske situasjonen. - I vår generasjon, og med 


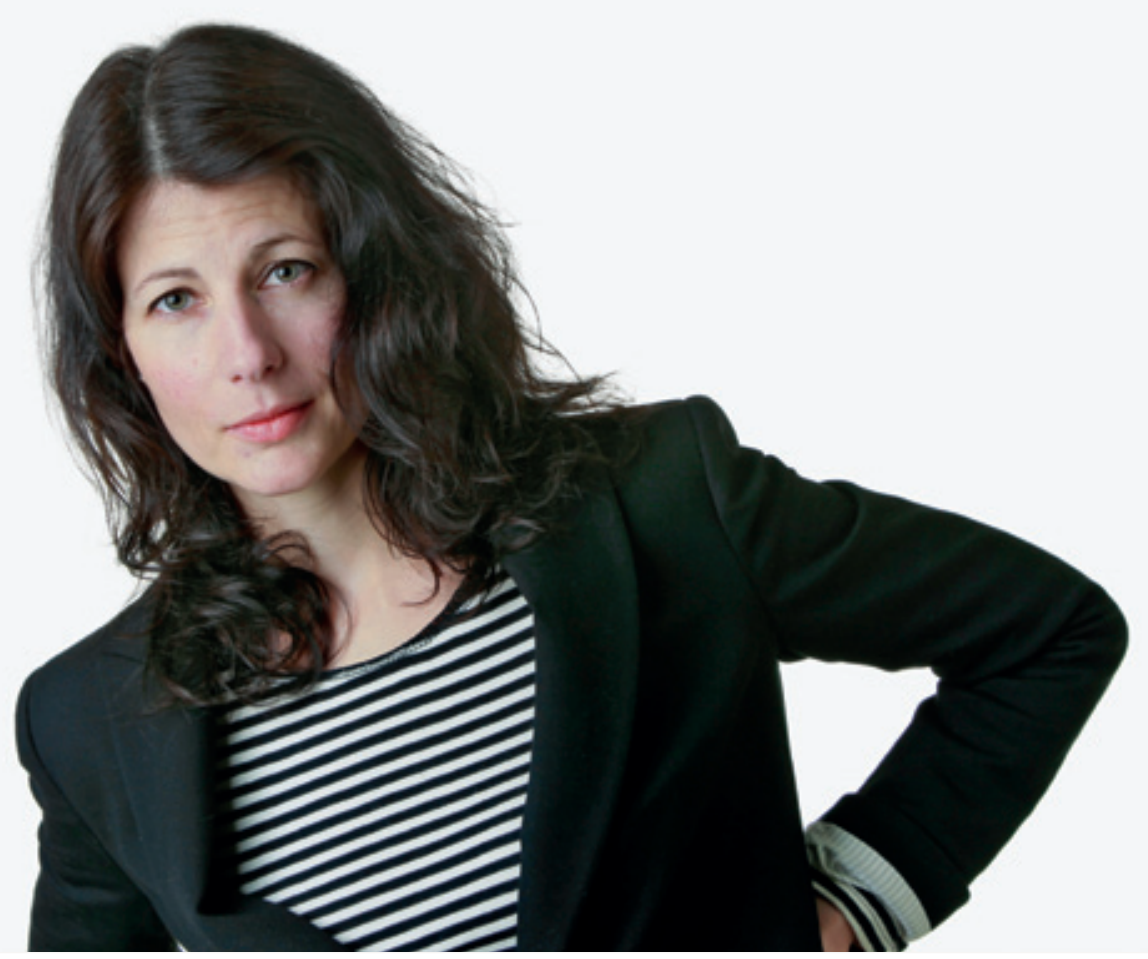

flere kvinner i faget, tror jeg det blir en annen samarbeidstone. Yngre leger i dag har ikke den samme autoritære holdningen til sine underordnede leger. Jeg husker en spesielt travel dag i turnus på kirurgen. Jeg sto på hodet i mottaket, klokken var fire om ettermiddagen og jeg hadde ennå ikke spist lunsj. Da fikk jeg en telefon fra en gastrokirurg som skjelte meg ut fordi jeg ikke hadde tatt imot en pasient oppe på post. Jeg prøvde å forklare situasjonen. «Sånn har vi alle hatt det!» avbrøt han surt. Dette er sikkert en del av sosialiseringen i miljøet, men slik tror jeg «hardcorespesialitetene» mister folk som hadde hatt verdifulle ting å bidra med. Jeg hørte en gang en flink overlege si at han var lei av å gå med boksehansker og knebeskyttere på jobb. Hvem orker egentlig det i lengden?

\section{Fordommer på begge hold}

- Hvilke reaksjoner får du blant leger på at du har vært og er journalist?

- For å være ærlig har jeg prøvd å holde det skjult. I sykehusturnus overhørte jeg en kollega som kommenterte noe jeg hadde skrevet i Journalen. Jeg fortet meg å gå før det ble sagt noe som kunne skade vårt videre samarbeid.

- Alle kjenner en eller annen som har hatt en uheldig erfaring med mediene, men jeg mener at leger og forskere i mye større grad kunne brukt mediene til sin fordel. Tenk om de kunne fylt offentligheten med kunnskap vi trenger i stedet for alt vi må lese om Mia Gundersens privatliv! Eias Hjernevask har vist hvilket potensial forskning har som mediestoff, hevder Charlotte.

Hun mener at helsepersonell og forskere som vil formidle noe via mediene må finne «sin» journalist. - Som sagt bruker ikke alltid journalisten informasjonen til det beste for intervjuobjektet, men som vitenskapsjournalist har jeg gode erfaringer med å jobbe frem saker sammen med forskere. Å mistro den man skal formidle informa- sjon til og igjennom er et dårlig utgangspunkt for samarbeid. Ryktene sier at journalister vrir og vrenger på det man sier, men den som intervjues får alltid lese igjennom sine sitater og rette opp feil.

- En journalistkollega kaller deg for tabloid, hva syns du om det?

- Det er ikke noe galt i å bruke store bokstaver om saken er viktig. Mange forveksler tabloidisering med vulgarisering. Jeg mener at vanskelige ting kan sies enkelt uten at det går på bekostning av innholdet. Det handler om tydeliggjøring. Det man gjør for å invitere leseren med seg inn i saken kaller vi $i$ journalistikken for spissing. Tabloid er ikke noe skjellsord for meg.

\section{Medial paranoia}

- Hva synes journalister om leger, da?

- Generelt har journalister respekt for leger, men leger har lett for å oppfattes som arrogante når de nekter å uttale seg og skjuler seg bak taushetsplikten. I sånne «gråtende pasienthistorier» som presenteres mener jeg det ofte er feil av leger ikke å uttale seg så lenge de er fridd fra taushetsplikten. Helsevesenet hadde tjent på større åpenhet.

- Ta Ali Farah-saken. Den er et eksempel på det jeg kaller «medial paranoia» og dårlig kommunikasjon fra ledelsen på Ullevål. Det gikk alt for lang tid før de gikk ut og kommenterte det som hadde skjedd. All pressedekning ble avvist og man skjøv på den måten ansvaret og medietrykket over på sjåførene og ambulansetjenesten i Oslo. Ikke en eneste journalist slapp til for å skrive om hvordan folk i ambulansetjenesten faktisk jobber, poengterer Charlotte.

- Slik er medienes enkle psykologi: De søker konflikt, og om de bare får «næring» fra én side av konflikten, vil de dyrke den. Begge sider må bidra med informasjon for at man skal få et balansert bilde. Du kan ikke stå på utsiden i en sånn storm.

- Samtidig gjør mediene også overtramp

\section{Charlotte Lunde}

\author{
Født 1970
}

- Cand.mag. med mellomfag i littera turvitenskap fra Universitetet i Oslo

- Fra 1990-årene journalist i Dagsavisen, Dagbladet og Aftenposten

- Programleder i Barne-TV (Etter skoletid, NRK) 1999-2001

- Frilansreporter i TV2 Nyhetene ved siden av medisinstudiene

- Cand.med. Universitetet i Oslo 2008

- Startet firmaet Medielegene.no med to kolleger i 2009

- Assistentlege ved barneavdelingen på Sørlandet sykehus, Arendal

Foto Berit Roald/SCANPIX

og feil. NRK Brennpunkts håndtering av programmet Det store Hjertelotteriet er et eksempel på dårlig journalistisk håndverk og spekulativ dramaturgi, hevder Charlotte. Studien som ble sterkt kritisert i programmet, har vist seg å få betydning for akuttmedisinsk behandling.

- Hva med pressedekningen av svineinfluensaen, hvordan vurderer du den?

- Der syns jeg Folkehelseinstituttet var flinke. De hadde én pressetalsmann, Bjørn Iversen, som var på jobb hele tiden. I samarbeid med pressen fungerte informasjonskampanjen som en folkehelseaksjon. Jeg synes ikke mediene krisemaksimerte utover det Folkehelsa gjorde. Men, det er klart at å stå med munnbind og rapportere fra gaten i Mexico gir en form for drama i formidlingen, lik det å stå med skuddsikker vest i Bagdad.

\section{Lundes laboratorium}

Mens Charlotte tok opp fag på Bjørknes for å komme inn på medisin, jobbet hun som programleder i Etter skoletid på NRK. Der hadde hun spalten Lundes laboratorium, hvor hun laget og fremførte sanger til sine favorittorganer sammen med jazzmusikeren Jacob Young. Da Charlotte skulle gifte seg i 2005, kom Trond Viggo Torgersen på besøk i utdrikningslaget.

- Han er jo en helt, ikke sant? Som takk måtte jeg synge Ode til Basilarmembranen for ham. Jeg har alltid vært opptatt av øret, det er liksom ansvarlig for musikkopplevelsen.

Av Trond Viggo fikk hun hans barnebok Kroppen med følgende dedikasjon: «Velkommen til feltet mellom media og medisin. Her trengs du!»

- Den kan jeg leve lenge på! ler hun.

\section{Guro Lenæs}

gurolenes@gmail.com

Medisinsk avdeling

Universitetssykehuset Nord-Norge - Harstad 